\title{
Pengaruh Kepemimpinan, Disiplin dan Motivasi Terhadap Kinerja Pegawai Dinas Tarukim Labura
}

\author{
Mhd. Edi Syahputra, Syaiful Bahri, Muis Fauzi Rambe \\ Program Magister Manajemen Pasca Sarjana \\ Universitas Muhammadiyah Sumatera Utara
}

Email: m.edis313@gmail.com

\author{
Naskah diterima 20 Maret 2020, Revisi 31 Maret 2020, Terbit 19 April 2020
}

\begin{abstract}
Abstrak
DOI: doi.org/10.21107/pamator.v13i1.7017

Sumber daya manusia merupakan faktor penggerak utama dari seluruh aktivitas perusahaan, karena peranan itulah tenaga kerja hendaknya mendapatkan perhatian yang lebih serius dari pihak perusahaan. Tujuan penelitian ini untuk mengetahui pengaruh kepemimpinan, disiplin kerja dan motivasi kerja terhadap kinerja pegawai di dinas perumahan dan kawasan pemukiman kabupaten labuhan batu utara. Populasi dalam penelitian ini adalah seluruh pegawai yang bekerja pada dinas perumahan dan dan kawasan pemukiman kab. Labuhan batu utara sebanyak 31 pegawai dan sampel yang dipakai adalah seluruh pegawai yang ada. Teknik pengumpulan data dalam penelitian ini yaitu dokumentasi dan daftar angket (kuisioner). Teknik analisis data menggunakan analisis regresi linier berganda, uji asumsi klasik uji $t$, uji $f$ dan koefisien determinasi. Pengolahan data dalam penelitian ini menggunakan program Software SPSS 22.00 for Windows. Berdasarkan hasil penelitian yang dilakukan, dari pengujian parsial kepemimpinan berpengaruh positif dan signifikan terhadap kinerja pegawai. Pengujian parsial pengaruh disiplin kerja berpengaruh positif dan signifikan terhadap kinerja pegawai. Pengujian parsial motivasi berpengaruh positif dan signifikan terhadap kinerja pegawai. Dan pengujian secara simultan pengaruh kepemimpinan, disiplin dan motivasi terhadap kinerja pegawai Menunjukkan bahwa kepemimpinan, disiplin kerja dan motivasi berpengaruh positif dan signifikan terhadap kinerja pegawai.
\end{abstract}

Kata kunci : kepemimpinan, disiplin kerja, motivasi, kinerja, regresi linear

\begin{abstract}
Human resources are the main driving factors of all corporate activities, because the role that Labor should get more serious attention from the company. The purpose of this research is to know the influence of leadership, work discipline and work motivation to the performance of employees in the housing service and residential areas of North Labuhan Batu. The population in this research is all employees who work in the housing department and the district residential area. The northern Labuhan Stone as many as 31 employees and the samples used are all employees. The data collection techniques in this study are documentation and questionnaire list. Data analysis techniques using multiple linear regression analyses, classical assumption Test T, Test fand coefficient of determination. Data processing in this study uses the program SPSS 22.00 for Windows Software. Based on the results of the research conducted, from the partial leadership testing influential positive and significant to the employee's performance. Partial testing of the influence of working discipline has a positive and significant impact on employee performance. A partial motivation test has a positive and significant impact on employee performance. And simultaneous testing of the influence of leadership, discipline and motivation towards employee performance demonstrated that leadership, discipline and motivation were positively and significantly impactful to employee performance.
\end{abstract}

Key Words: leadership, work discipline, motivation, performance, linear regression

\section{PENDAHULUAN}

Sumber daya manusia dapat dijadikan tolok ukur prestasi organisasi dalam menciptakan kebutuhan organisasi, yaitu aparatur yang terjamin kredibilitas dan kompetensi karena tercukupi tingkat kesejahteraan dengan gaji yang baik dan tingkat produktivitas yang optimal. Kinerja pegawai yang baik merupakan bangunan kinerja yang optimal yaitu kinerja yang sesuai standar organisasi dan mendukung tercapainya tujuan organisasi pemerintahan. Organisasi yang baik dalam tataran pemerintahan merupakan organisasi yang 
berusaha meningkatkan kemampuan sumber daya manusianya, karena hal tersebut merupakan faktor kunci untuk meningkatkan kinerja pegawai kelurahan.

Kinerja dapat diukur dengan kuantitas kerja, kualitas kerja, kesetiaan bekerja, kemampuan kerja dan hasil yang dicapai. Kinerja telah menjadi kerangka pikir sentral untuk dijadikan pemicu pencapaian tujuan organisasi. Perusahaan ataupun organisasi dapat berjalan sesuai dengan harapan yang telah ditetapkan, apabila didalamnya terdapat manusia dengan satu tujuan yang sama, yaitu berkeinginan untuk menjadikan perusahaan tempat dia bekerja dan mencari nafkah mengalami peningkatan keuntungan serta perkembangan dari tahun ke tahun. Kinerja pegawai memiliki peran penting dalam mencapai tujuan dan sasaran organisasi sesuai dengan visi dan misi yang ada. Untuk itu sangat tergantung dari pelaksanaannya yaitu para pegawai agar mencapai sasaran yang telah ditetapkan oleh organisasi.

Sumber daya manusia merupakan faktor penggerak utama dari seluruh aktivitas perusahaan, karena peranan itulah tenaga kerja hendaknya mendapatkan perhatian yang lebih serius dari pihak perusahaan. Beberapa faktor yang mempengaruhi kinerja seperti kepemimpinan, disiplin dan motivasi sangat berpengaruh untuk meningkatkan kinerja karyawan. Peran pemimpin dalam pengembangan fungsi manajemen pun sangat penting untuk melaksanakan, mengkoordinasi, menggerakkan dan mengatur bawahannya dengan sebaik mungkin agar mereka dapat memenuhi harapan organisasi dan mencapai tujuan organisasi tersebut.

Setiap individu memiliki kebutuhan dan keinginan yang berbeda-beda pula. Pemimpin harus fleksibel dalam pemahaman segala potensi yang dimiliki oleh individu dan berbagai permasalahan yang dihadapi individu tersebut. Dengan melakukan pendekatan tersebut, pemimpin dapat menerapkan segala peraturan dan kebijakan organisasi serta melimpahkan tugas dan tanggung jawab dengan tepat. Begitu juga halnya dengan penanganan disiplin kerja, disiplin kerja yang baik dimaksudkan agar perusahaan dapat memberikan pengaruh dan dorongan serta motivasi kepada karyawan sehingga dapat meningkat kan kinerja pegawai. Menurut Mangkunegara (2013) disiplin kerja dapat diartikan sebagai pelaksaan manajemen untuk memperteguh pedoman-pedoman organisasi. Disiplin kerja yang baik akan mendorong dan memotivasi karyawan kerja dengan baik. Motivasi merupakan kondisi yang menggerakkan diri pegawai yang terarah untuk mencapai tujuan organisasi, dalam hal ini ada hubungan yang positif antara motif berprestasi dengan pencapaian kinerja (Mangkunegara, 2013). Sedangkan menurut Rivai (2009) motivasi adalah serangkaian sikap dan nilai nilai yang mempengaruhi individu untuk mencapai hal yang spesifik sesuai denga tujuan individu. Dapat diyakini bahwa pada dasarnya setiap manusia memiliki motivasi untuk melakukan pekerjaan, sehingga melalui motivasi berarti ada dorongan yang kuat baik internal maupun eksternal pada diri seseorang untuk melakukan sesuatu yang lebih dari apa yang dilakukan orang lain.

Dinas Perumahan dan pemukiman adalah salah satu dinas yang berada di Kabupaten Labuhan batu Utara yang didirikan berdasarkan peraturan Bupati Nomor 37 tahun 2016. Dinas Perumahan dan pemukiman memiliki tugas sebagai pembantu urusan pemerintah untuk menyusun dan melaksanakan kebijakan bidang perumahan, pertanahan dan pemukiman di daerah kabupaten Labuhan Batu Utara. Fungsi utamanya adalah merumuskan kebijkan bidang perumahan, pemukiman dan pertanahan seperti pengurusan izin membuka lahan, izin pengembangan dan dan penyehatan lingkungan pemukiman. Didalam melaksanakan tugasnya pegawai dinas perumahan dan pemukiman juga dituntut agar kinerja sesuai yang diharapkan oleh pimpinan dan masyarakat seperti perlunya peningkatan disiplin kerja pegawai. Dengan adanya sikap disiplin, maka kinerja pegawai di Kantor dinas perumahan dan pemukiman di labuhan batu utara dapat diselesaikan dengan tepat waktu, sehingga masih ada kesempatan untuk memperbarui dan mengevaluasi hasil kinerja.

Menurut Mangkunegara (2013) Kinerja adalah hasil kerja secara kualitas dan kuantitas yang dicapai oleh seorang karyawan dalam melaksanakan tugasnya sesuai dengan tanggung jawab yang 
diberikan kepadanya. Robbins (2006) menjelaskan kinerja pegawai adalah sebagai fungsi dan interaksi antara kemampuan dan motivasi. Sedangkan menurut Rivai (2009) kinerja merupakan suatu fungsi dari motivasi dan kemampuan untuk menyelesaikan tugas atau pekerjaan seorang sepatutnya memiliki derajat kesediaan dan tingkat kemampuan tertentu. Menurut Sulaksono (2015) kinerja merupakan hasil kerja secara kualitas dan kuantitas yang dapat dicapai oleh seorang pegawai dalam melaksanakan tugas sesuai dengan tanggung jawab yang diberikan kepadanya.

Pemimpin tidak dapat menggunakan kepemimpinan yang sama dalam memimpin bawahannya, namun harus disesuaikan dengan karakter- karakter tingkat kemampuan dalam tugas setiap bawahannya. Menurut Bangun (2012). Sedangkan menurut Hasibuan (2012), kepemimpinan juga dikatakan cara mempengaruhi perilaku bawahan, agar mau bekerja sama dan bekerja secara produktif untuk mencapai tujuan organisasi. Masalah kepemimpinan telah muncul bersamaan dengan dimulainya sejarah manusia yaitu sejak manusia menyadari pentingnya hidup berkelompok untuk mencapai tujuan bersama. Mereka membutuhkan seseorang atau beberapa orang yang mempunyai kelebihan-kelebihan daripada yang lain, terlepas dalam bentuk apa kelompok manusia itu dibentuk.

Menurut Hasibuan (2012) disiplin adalah suatu sikap, tingkah laku, dan perbuatan seseorang yang sesuai dengan peraturan perusahaan, baik yang tertulis maupun tidak. Sedangkan menurut Rivai (2009) disiplin kerja adalah suatu alat yang digunakan para manajer untuk berkomunikasi dengan karyawan agar mereka bersedia untuk mengubah suatu perilaku serta sebagai suatu upaya untuk meningkatkan kesadaran dan kesediaan seseorang menaati semua peraturan perusahaan dan norma-norma social yang berlaku. Dan menurut Hasibuan (2002) Disiplin kerja adalah kesadaran dan kesediaan seseorang menaati semua peraturan dan norma-norma social yang berlaku.

Menurut Rivai (2009) Motivasi adalah serangkaian sikap dan nilai-nilai yang mempengaruhi individu untuk mencapai hal yang spesifik sesuai dengan tujuan individu.

Sedangkan menurut Handoko (2007) motivasi merupakan kondisi yang menggerakkan diri pegawai yang terarah untuk mencapai tujuan organisasi, dalam hal ini ada hubungan yang positif antara motif berprestasi dengan pencapaian kinerja. Dapat diyakini bahwa pada dasarnya setiap manusia memiliki motivasi untuk melakukan pekerjaan, sehingga melalui motivasi berarti ada dorongan yang kuat baik internal maupun eksternal pada diri seseorang untuk melakukan sesuatu yang lebih dari apa yang dilakukan orang lain. Dengan kata lain motivasi kerja adalah sesuatu yang menggerakkan seseorang untuk bertindak dengan cara tertentu atau sekurangkurangnya mengembangkan cara tertentu sebagai wujud seseorang yang memiliki motivasi keberhasilan yang tinggi.

Sumber daya manusia merupakan faktor penggerak utama dari seluruh aktivitas perusahaan, karena peranan itulah tenaga kerja hendaknya mendapatkan perhatian yang lebih serius dari pihak perusahaan. Beberapa faktor yang mempengaruhi kinerja seperti kepemimpinan, disiplin dan motivasi sangat berpengaruh untuk meningkatkan kinerja karyawan. Peran pemimpin dalam pengembangan fungsi manajemen pun sangat penting untuk melaksanakan, mengkoordinasi, menggerakkan dan mengatur bawahannya dengan sebaik mungkin agar mereka dapat memenuhi harapan organisasi dan mencapai tujuan organisasi tersebut. Penelitian terdahulu yang dilakukan oleh (Posuma, 2013) menunjukkan bahwa kepemimpinan berpengaruh signifikan terhadap kinerja pegawai.

Disiplin kerja merupakan alat yang digunakan para manajer untuk berkomunikasi dengan karyawan agar mereka bersedia untuk mengubah suatu perilaku serta sebagai suatu upaya untuk meningkatkan kesadaran dan kesediaan seseorang menaati semua peraturan perusahaan dan meningkat kan kinerja untuk dapat mencapai tujuan perusahaan. Penelitian terdahulu yang dilakukan oleh (Nurcahya, 2018) dan (Primadi, 2017) menunjukkan bahwa disiplin kerja berpengaruh signifikan terhadap kinerja pegawai. 
Motivasi adalah pendorong (penggerak) yang ada dalam diri seseorang untuk bertindak dan melakukan pekerjaan. Konsep motivasi dalam berbagai literatur seringkali ditekankan pada rangsangan yang muncul dari seseorang baik dari dalam (motivasi intrinsik), maupun dari luar (motivasi ekstrinsik). Penelitian terdahulu yang dilakukan oleh (Lutfi, 2014) dan (Damayanti, 2013) menunjukkan bahwa motivasi berpengaruh signifikan terhadap kinerja pegawai.

Suatu perusahaan atau organisasi yang mampu meningkatkan kerja karyawannya, maka akan memperoleh banyak keuntungan. Karyawan yang mempunyai kinerja yang produktif, maka pekerjaan akan lebih cepat diselesaikan. Hal ini semua berarti diharapkan bukan saja produktivitas kerja dapat ditingkatkan namun juga efisiensi dari pekerjaan tersebut. Salah satu faktor yang mempengaruhi efektifitas dari kerja adalah pemberian motivasi sertadorongan untuk memacu pegawai dapat bekerja secara baik. Begitu juga halnya dengan tingkat kesiplinan pegawai, apabila pegawai disiplin dan tepat waktu dalam melaksanakan tugasnya maka perusahaan akan diuntungkan dengan membaiknya kinerja pegawai.

\section{METODOLOGI}

Penelitian ini menggunakan jenis penelitian asosiatif. Penelitian asosiatif menurut Sugiyono (2008) adalah penelitian yang dilakukan untuk menggabungkan antara dua variabel atau lebih guna mengetahui pengaruh antara variabel satu dengan yang lainnya. dengan menggunakan pendekatan deskriptif kuantitatif yang menggambarkan dan meringkaskan berbagai kondisi, situasi atau variabel. Variabel yang digunakan pada penelitian ini adalah kinerja, kepemimpinan, disiplin kerja dan motivasi. Penelitian ini dilakukan di Dinas Perumahan Dan kawasan Pemukiman Kabupaten Labuhanbatu Utara. Peneliti melakukan pengambilan sampel dengan teknik sampel jenuh. Menurut Sugiyono (2018) Sampel jenuh merupakan teknik pengambilan sampel yang memperhatikan nilai kejenuhan sampel. Peneliti menggunakan seluruh sampel menjadi populasi sebanyak 31 orang. teknik pengumpulan data yang digunakan dalam penelitian ini yaitu dengan menyebarkan daftar pertanyaan berstruktur kepada responden yang dijadikan sebagai sampel, dimana responden dapat memilih salah satu alternatif jawaban yang disediakan. Teknik analisis data menggunakan uji asumsi klasik, uji hipotesis, koefisien determinasi dan regresi linier berganda yang menggunakan rumus :

$$
\begin{aligned}
& Y=a+b_{1} X_{1}+b_{2} X_{2}+b_{3} X_{3}+e \\
& Y= \text { Kinerja } \\
& a= \text { Konstanta } \\
& X_{1}=\text { Kepemimpinan } \\
& X_{2}=\text { Disiplin Kerja } \\
& X_{3}=\text { Motivasi Kerja } \\
& e=\text { Term error }
\end{aligned}
$$

\section{HASIL DAN PEMBAHASAN}

\section{Uii Asumsi Klasik Normalitas}

Pengujian normalitas data dilakukan untuk melihat apakah dalam model regresi variabel dependen dan independen memiliki distribusi normal atau tidak. Jika data menyebar disekitar garis diagonal dan mengikuti arah garis diagonal, maka model regresi memenuhi asumsi normalitas. Gambar 1 mengidentifikasi bahwa model regresi telah memenuhi asumsi yang telah dikemukakan sebelumnya, sehingga data dalam model regresi penelitian ini dikatakan normal

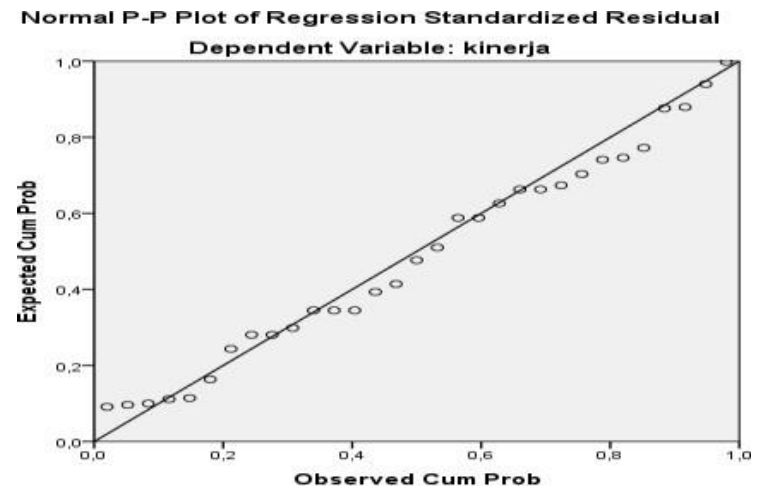

Gambar 1. Hasil Uji Normalitas

\section{Uii Multikolinearitas}

Model regresi ini digunakan untuk menguji apakah pada model regresi ditemukan adanya korelasi yang kuat antara variabel independen. Cara yang digunakan untuk menilainya adalah dengan melihat nilai factor inflasi varian (Variabel Inflation Factor/VIF) yang tidak melebihi 4 atau 5. 
Ketiga variabel independen yakni kepemimpinan $\left(X_{1}\right)$, disiplin kerja $\left(X_{2}\right)$ dan motivasi kerja $\left(X_{3}\right)$ memiliki nilai VIF dalam batas toleransi yang telah ditentukan (tidak melebihi 4 atau 5), sehingga tidak terjadi multikolinearitas dalam variabel independen pada penelitian ini.

Tabel 1. Hasil Uji Multikolinearitas

\begin{tabular}{|c|c|c|c|}
\hline \multirow{2}{*}{\multicolumn{2}{|c|}{ Model }} & \multicolumn{2}{|c|}{ Collinearity Statistics } \\
\hline & & \multirow[t]{2}{*}{ Tolerance } & \multirow[t]{2}{*}{ VIF } \\
\hline 1 & (Constant) & & \\
\hline & Kepemimpinan & ,206 & 7,663 \\
\hline & Disiplin Kerja & 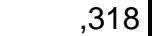 & 5,302 \\
\hline & Motivasi Kerja & , 403 & 9,741 \\
\hline
\end{tabular}

\section{Uji Heterokedastisitas}

Asumsi klasik heterokedastisitas digunakan untuk menguji apakah dalam model regresi terjadi ketidakpastian varians dari variabel suatu pengamatan yang lain. Jika varians residual dari satu pengamatan yang lain tetap maka disebut homokedastisitas dan jika varians berbeda disebut heterokedastisitas. Model baik adalah tidak terjadi heterokedastisitas. Jika tidak ada pola yang jelas, serta titik-titik menyebar dibawah dan diatas angka 0 pada sumbu, maka tidak terjadi heterokedastisitas.

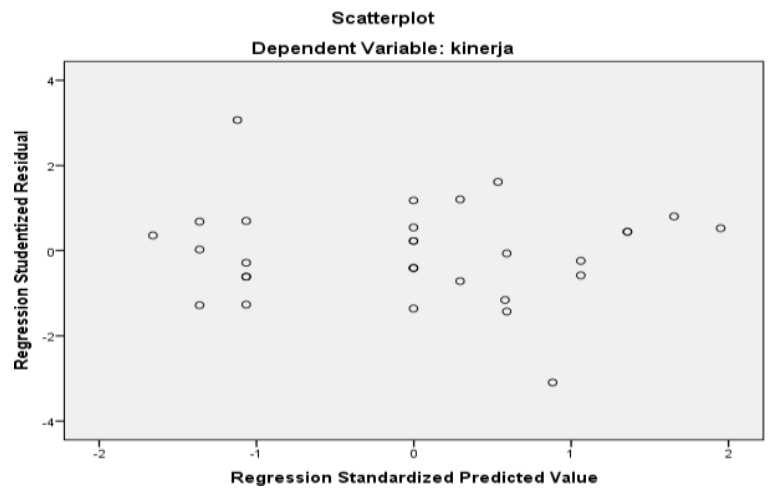

Gambar 2. Hasil Uji Normalitas

Gambar 2 di atas memperlihatkan titik menyebar secara acak, tidak membentuk pola yang jelas/teratur, serta tersebar baik di atas maupun di bawah angka 0 pada sumbu Y. Dengan demikian tidak terjadi heterokedastisitas pada model regresi.

\section{Uji Regresi Linier Berganda}

Untuk mengetahui keeratan dari hasil pengolahan data dengan SPSS tentang pengaruh kepemimpinan $\left(X_{1}\right)$, disiplin kerja $\left(X_{2}\right)$ dan motivasi kerja $\left(X_{3}\right)$ terhadap kinerja (Y) pada Dinas Perumahan Dan Pemukiman Kabupaten Labuhan batu Utara maka dapat digunakan regresi linier berganda. Persamaan regresi linier berganda dapat dilihat dari nilai koefisien pada Tabel berikut :

Tabel 2. Hasil Regresi Linear Berganda

\begin{tabular}{|l|l|r|r|}
\hline \multicolumn{2}{|l|}{} & \multicolumn{2}{c|}{$\begin{array}{c}\text { Unstandardized } \\
\text { Coefficients }\end{array}$} \\
\cline { 2 - 4 } \multicolumn{2}{|l|}{ Model } & \multicolumn{1}{c|}{ B } & Std. Error \\
\hline 1 & (Constant) & 24,628 & 3,848 \\
\cline { 2 - 4 } & Kepemimpinan &, 722 & 1,306 \\
\cline { 2 - 4 } & Disiplin Kerja &, 431 &, 586 \\
\cline { 2 - 4 } & Motivasi kerja &, 683 & 1,823 \\
\hline
\end{tabular}

Dari perhitungan dengan menggunakan aplikasi SPSS versi 21 didapat hasil :

$$
\begin{gathered}
Y=a+b_{1} X_{1}+b_{2} X_{2}+b_{3} X_{3}+e \\
Y=24,628+0,722 X_{1}+0,431 X_{2}+0,683 X_{3}
\end{gathered}
$$

Konstanta mempunyai nilai regresi sebesar 24,628, artinya jika variable kepemimpinan, disiplin kerja dan motivasi kerja dianggap nol, maka ada kenaikan kinerja pegawai sebesar 24,628. Kepemimpinan $\left(X_{1}\right)$ mempunyai koefisien regresi sebesar 0,722 dengan arah positif, artinya bahwa setiap kenaikan variabel pelatihan sebesar 1\%, maka akan terjadi peningkatan Kinerja sebesar $72 \%$. Disiplin kerja $\left(X_{2}\right)$ mempunyai koefisien regresi sebesar 0,431 dengan arah positif, artinya bahwa setiap kenaikan variabel disiplin kerja sebesar $1 \%$, maka akan terjadi peningkatan kinerja karyawan sebesar 43,1\%. Motivasi Kerja $\left(X_{3}\right)$ mempunyai koefisien regresi sebesar 0,683 dengan arah positif, artinya bahwa setiap kenaikan variabel motivasi kerja sebesar $1 \%$, maka akan terjadi peningkatan kinerja karyawan sebesar 68,3 $\%$. 


\section{Uii Hipotesis Parsial (Uii t)}

Uji t adalah pengujian yang dilakukan untuk mengetahui hubungan variabel bebas terhadap variabel terkait secara parsial. Dimana uji $t$ mencari thitung dan membandingkan dengan $t_{\text {tabel }}$ apakah variabel independen secara parsial memiliki pengaruh yang signifikan atau tidak dengan variabel dependen.

Tabel 3. Hasil Uji-t

\begin{tabular}{|l|l|c|c|}
\hline \multicolumn{2}{|l|}{ Model } & \multicolumn{1}{c|}{ S } & Sig. \\
\hline 1 & (Constant) & 6,400 &, 000 \\
\cline { 2 - 4 } & Kepemimpinan & 3,591 &, 009 \\
\cline { 2 - 4 } & Disiplin Kerja & 2,736 &, 008 \\
\cline { 2 - 4 } & Motivasi kerja & 2,373 &, 002 \\
\hline
\end{tabular}

Pengaruh Kepemimpinan $\left(X_{1}\right)$ terhadap Kinerja ( $Y$ )

Variabel kepemimpinan $\left(X_{1}\right)$ terhadap kinerja $(Y)$ diperoleh nilai $t_{\text {hitung }}$ sebesar 3,591 lebih besar dari $t_{\text {tabel }}$ 1,703 dengan nilai probabilitas (sig) 0,009 lebih kecil dari a 0,05 , dapat disimpulkan bahwa $\mathrm{H}_{0}$ ditolak dan $\mathrm{H}_{\mathrm{a}}$ diterima, artinya kepemimpinan $\left(\mathrm{X}_{1}\right)$ berpengaruh signifikan terhadap kinerja $(Y)$ pada Dinas Perumahan dan Pemukiman Kabupaten Labuhan Batu Utara.

\section{Pengaruh Disiplin Kerja $\left(X_{2}\right)$ terhadap Kinerja $(Y)$}

Variabel disiplin kerja $\left(X_{2}\right)$ terhadap kinerja $(Y)$ diperoleh nilai $t_{\text {hitung }}$ sebesar 2,736 lebih besar dari $t_{\text {tabel }} 1,703$ dengan nilai probabilitas (sig) 0,008 lebih kecil dari a 0,05 , dapat disimpulkan bahwa $\mathrm{H}_{0}$ ditolak dan $\mathrm{H}_{\mathrm{a}}$ diterima, artinya disiplin kerja $\left(\mathrm{X}_{2}\right)$ berpengaruh signifikan terhadap kinerja $(\mathrm{Y})$ pada Dinas Perumahan dan Pemukiman Kabupaten Labuhan Batu Utara.

Pengaruh Motivasi kerja $\left(X_{3}\right)$ Terhadap Kinerja ( $Y$ )

Variabel motivasi kerja $\left(X_{3}\right)$ terhadap kinerja $(Y)$ diperoleh nilai $t_{\text {hitung }}$ sebesar 2,373 lebih besar dari $t_{\text {tabel }} 1,703$ dengan nilai probabilitas (sig) 0,007 lebih kecil dari a 0,05, dapat disimpulkan bahwa $\mathrm{H}_{0}$ ditolak dan $\mathrm{H}_{\mathrm{a}}$ diterima, artinya motivasi kerja $\left(\mathrm{X}_{3}\right)$ berpengaruh signifikan terhadap kinerja $(\mathrm{Y})$ pada Dinas Perumahan dan Pemukiman Kabupaten Labuhan Batu Utara.

\section{Uji Simultan (Uji F)}

Uji simultan atau uji $F$ dimaksudkan untuk melihat kemampuan menyeluruh dari variabel bebas yaitu kepemimpinan $\left(X_{1}\right)$, disiplin kerja $\left(X_{2}\right)$ dan motivasi kerja $\left(X_{3}\right)$ terhadap kinerja $(Y)$. Uji $F$ juga dimaksud untuk mengetahui apakah semua variabel memiliki koefisien sama dengan nol dengan ketentuan jika nilai probabilitas $\mathrm{F}$ (sig) pada Tabel Anova lebih kecil dari $\alpha=0,05$.

Tabel 4. Hasil Uji Anova

\begin{tabular}{|l|l|r|r|c|r|}
\hline \multicolumn{2}{|l|}{ Model } & $\begin{array}{r}\text { Sum of } \\
\text { Square } \\
\text { s }\end{array}$ & $\begin{array}{r}\text { D } \\
f\end{array}$ & F & Sig. \\
\hline & $\begin{array}{l}\text { Regressio } \\
\mathrm{n}\end{array}$ & 309,169 & 3 & $\begin{array}{c}9,96 \\
5\end{array}$ & $\begin{array}{r}000 \\
\mathrm{~b}\end{array}$ \\
\cline { 1 - 3 } 1 & Residual & 279,218 & 27 & & \\
\cline { 1 - 3 } & Total & 588,387 & 30 & & \\
\hline
\end{tabular}

Nilai $F_{\text {hitung }}$ pada Tabel di atas adalah 9,965 lebih besar dari $F_{\text {tabel }} 2,96$ dengan sig. 0,000 lebih kecil dari a 0,05. Menunjukkan $\mathrm{H}_{0}$ ditolak dan $\mathrm{H}_{\mathrm{a}}$ diterima, berarti kepemimpinan $\left(X_{1}\right)$, disiplin kerja $\left(X_{2}\right)$ dan motivasi kerja $\left(X_{3}\right)$ berpengaruh secara signifikan terhadap kinerja $(\mathrm{Y})$ pada Dinas Perumahan dan Pemukiman Kabupaten Labuhan Batu Utara.

\section{Koefisien Determinasi}

Koefisien Determinasi $\left(R^{2}\right)$ berfungsi untuk melihat sejauh mana keseluruhan variabel independent dapat menjelaskan variabel dependent. Nilai koefisien determinasi adalah antara 0 dan 1. Apabila angka koefisien determinasi semakin kuat, yang berarti variabel-variabel independent memberikan hampir semua informasi yang dibutuhkan untuk memprediksi variasi variabel dependent.

Tabel 5. Hasil Koefisien Determinasi

\begin{tabular}{|c|c|c|c|}
\hline $\mathrm{R}$ & $\begin{array}{l}\mathrm{R} \\
\text { Square }\end{array}$ & $\begin{array}{l}\text { Adjusted R } \\
\text { Square }\end{array}$ & $\begin{array}{l}\text { Std. Error of } \\
\text { the Estimate }\end{array}$ \\
\hline & ,525 & ,473 & 3,21581 \\
\hline
\end{tabular}


Pada tabel Model Summary diperoleh nilai $\mathrm{R}^{2}=0,525$. Artinya, variabel independent (kepemimpinan, disiplin kerja dan motivasi kerja) dapat menerangkan variabilitas sebesar $52,5 \%$ dari variabel dependent (kinerja), sedangkan sisanya 47,5\% diterangkan oleh variabel lain yang tidak diteliti dalam penelitian ini.

\section{Pengaruh Kepemimpinan $\left(X_{2}\right)$ terhadap Kinerja ( $Y$ )}

Berdasarkan hasil uji hipotesis secara parsial (uji t) yang diperoleh mengenai pengaruh kepemimpinan $\left(X_{1}\right)$ terhadap kinerja $(Y)$ diperoleh nilai $t_{\text {hitung }}$ sebesar 3,591 lebih besar dari $t_{\text {tabel }} 1,703$ dengan nilai probabilitas (sig) 0,009 lebih kecil dari a 0,05 , dapat disimpulkan bahwa $\mathrm{H}_{0}$ ditolak dan $\mathrm{H}_{\mathrm{a}}$ diterima, artinya kepemimpinan $\left(\mathrm{X}_{1}\right)$ berpengaruh signifikan terhadap kinerja $(Y)$ pada Dinas Perumahan dan Pemukiman Kabupaten Labuhan Batu Utara.

Hasil pengujian statistik menunjukkan bahwa pengaruh kepemimpinan terhadap terhadap kinerja ( $Y$ ) pada Dinas Perumahan dan Pemukiman Kabupaten Labuhan Batu Utara. Hasil penelitian ini sejalan dengan penelitian yang dilakukan oleh (Posuma, 2013) menunjukkan bahwa kepemimpinan berpengaruh signifikan terhadap kinerja pegawai. Kepemimpinan didefinisikan sebagai suatu ilmu yang mengkaji secara komprehensif bagaimana mengarahkan, mempengaruhi dan mengawasi orang lain untuk mengerjakan tugas sesuai dengan perintah yang direncanakan (Fahmi, 2016).

\section{Pengaruh Disiplin $\left(X_{2}\right)$ Kerja terhadap Kinerja ( $Y$ )}

Berdasarkan hasil uji hipotesis secara parsial (uji t) yang diperoleh mengenai pengaruh disiplin kerja $\left(\mathrm{X}_{2}\right)$ terhadap kinerja (Y) diperoleh nilai $t_{\text {hitung }}$ sebesar 2,736 lebih besar dari $t_{\text {tabel }} 1,703$ dengan nilai probabilitas (sig) 0,008 lebih kecil dari a 0,05, dapat disimpulkan bahwa $\mathrm{H}_{0}$ ditolak dan $\mathrm{H}_{\mathrm{a}}$ diterima, artinya disiplin kerja $\left(\mathrm{X}_{2}\right)$ berpengaruh signifikan terhadap kinerja $(\mathrm{Y})$ pada Dinas Perumahan dan Pemukiman Kabupaten Labuhan Batu Utara. Hasil pengujian statistik menunjukkan bahwa pengaruh disiplin kerja $\left(\mathrm{X}_{2}\right)$ terhadap kinerja (Y) pada Dinas Perumahan dan Pemukiman Kabupaten Labuhan Batu Utara. Hasil penelitian ini sejalan dengan penelitian yang dilakukan oleh yang dilakukan oleh (Nurcahya, 2018) dan (Primadi, 2017) menunjukkan bahwa disiplin kerja berpengaruh signifikan terhadap kinerja pegawai. Disiplin merupakan bentuk ketaatan atau kepatuhan terhadap peraturan yang berlaku baik yang tertulis maupun tidak tertulis. Hasibuan (2011) mengemukakan bahwa disiplin kerja adalah kesadaran dan kesediaan seseorang mentaati semua peraturan perusahaan dan norma- norma social yang berlaku. Disiplin kerja merupakan alat yang digunakan para manajer untuk berkomunikasi dengan karyawan agar mereka bersedia untuk mengubah suatu perilaku serta sebagai suatu upaya untuk meningkatkan kesadaran dan kesediaan seseorang menaati semua peraturan perusahaan dan meningkat kan kinerja untuk dapat mencapai tujuan perusahaan.

\section{Pengaruh Motivasi kerja $\left(X_{3}\right)$ terhadap Kinerja ( $Y$ )}

Berdasarkan hasil uji hipotesis secara parsial (uji t) yang diperoleh mengenai pengaruh motivasi kerja $\left(X_{3}\right)$ terhadap kinerja (Y) diperoleh nilai $t_{\text {hitung }}$ sebesar 2,373 lebih besar dari $t_{\text {tabel }} 1,703$ dengan nilai probabilitas (sig) 0,007 lebih kecil dari a 0,05, dapat disimpulkan bahwa $\mathrm{H}_{0}$ ditolak dan $\mathrm{H}_{\mathrm{a}}$ diterima, artinya motivasi kerja $\left(X_{3}\right)$ berpengaruh signifikan terhadap kinerja $(Y)$ pada Dinas Perumahan Dan Pemukiman Kabupaten Labuhan Batu Utara.

Hasil pengujian statistik menunjukkan bahwa pengaruh motivasi kerja terhadap terhadap kinerja $(\mathrm{Y})$ pada Dinas Perumahan dan Pemukiman Kabupaten Labuhan Batu Utara. Hal ini sejalan dengan Penelitian terdahulu yang dilakukan oleh (Lutfi, 2014) dan (Damayanti, 2013) menunjukkan bahwa motivasi berpengaruh signifikan terhadap kinerja pegawai. Menurut Stanford (dalam Mangkunegara, 2013) bahwa "Motivation as an energizing condition of the organism that serves to direct that organism toword the goal of a certain class", motivasi sebagai suatu kondisi yang menggerakkan manusia kearah suatu tujuan tertentu. Tujuan diberikannya motivasi adalah agar dapat mempengaruhi kinerja pegawai kearah yang lebih baik. 
Pengaruh Kepemimpinan $\left(X_{1}\right)$, Disiplin Kerja $\left(X_{2}\right)$ dan Motivasi Kerja $\left(X_{3}\right)$ terhadap Kinerja (Y)

Berdasarkan hasil uji hipotesis secara simultan (uji F) yang diperoleh mengenai pengaruh kepemimpinan, disiplin kerja dan motivasi kerja Nilai $F_{\text {hitung }}$ pada Tabel di atas adalah 9,965 lebih besar dari $F_{\text {tabel }} 2,96$ dengan sig. 0,000 lebih kecil dari a 0,05. Menunjukkan $\mathrm{H}_{0}$ ditolak dan $\mathrm{H}_{\mathrm{a}}$ diterima, berarti kepemimpinan $\left(X_{1}\right)$, disiplin kerja $\left(X_{2}\right)$ dan motivasi kerja $\left(X_{3}\right)$ berpengaruh secara signifikan terhadap kinerja $(\mathrm{Y})$ pada Dinas Perumahan dan Pemukiman Kabupaten Labuhan Batu Utara.

Suatu perusahaan atau organisasi yang mampu meningkatkan kerja karyawannya, maka akan memperoleh banyak keuntungan. Karyawan yang mempunyai kinerja yang produktif, maka pekerjaan akan lebih cepat diselesaikan. Hal ini semua berarti diharapkan bukan saja produktivitas kerja dapat ditingkatkan namun juga efisiensi dari pekerjaan tersebut. Salah satu faktor yang mempengaruhi efektifitas dari kerja adalah pemberian motivasi sertadorongan untuk memacu pegawai dapat bekerja secara baik. Begitu juga halnya dengan tingkat kesiplinan pegawai, apabila pegawai disiplin dan tepat waktu dalam melaksanakan tugasnya maka perusahaan akan diuntungkan dengan membaiknya kinerja pegawai.

\section{KESIMPULAN}

Berdasarkan hasil uji hipotesis secara parsial yang diperoleh mengenai pengaruh kepemimpinan terhadap kinerja dapat disimpulkan bahwa kepemimpinan berpengaruh signifikan terhadap kinerja pada Dinas Perumahan Dan Pemukiman Kabupaten Labuhan Batu Utara, disiplin kerja berpengaruh signifikan terhadap kinerja pada Dinas Perumahan Dan Pemukiman Kabupaten Labuhan Batu Utara, motivasi kerja berpengaruh signifikan terhadap kinerja pada Dinas Perumahan dan Pemukiman Kabupaten Labuhan Batu Utara dan hasil uji hipotesis secara simultan mengenai pengaruh kepemimpinan, disiplin kerja dan motivasi kerja dapat disimpulkan kepemimpinan, disiplin kerja dan motivasi kerja berpengaruh secara signifikan terhadap kinerja pada Dinas Perumahan dan Pemukiman Kabupaten Labuhan Batu Utara.

\section{DAFTAR PUSTAKA}

Damayanti, A, P., Susilaningsih., Sumaryati, S. 2013. Pengaruh Kepemimpinan Dan Motivasi Kerja Terhadap Kinerja Karyawan Perusahaan Daerah Air Minum (PDAM) Surakarta. Jurnal FKIP Universitas Sebelas Maret. Vol 2. No 1. 155-168 pp.

Fahmi, I. 2016. Pengantar Manajemen Sumber Daya Manusia. Cetakan Pertama.Jakarta : Mitra Wacana Media

Hasibuan, M.S.P. 2012. Manajemen Sumber Daya Manusia. Jakarta: PT.Bumi Aksara

Luhfti, R.I. 2014. Pengaruh Motivasi Terhadap Kinerja Karyawan (Studi Pada PT Ebiscom Prima Karya, Kantor Perwakilan Surabaya). Jurnal Administrasi Bisnis (JAB). Vol 13. No. 1. 1-8 pp.

Mangkunegara, A.P. 2013. Manajemen Sumber Daya Manusia Perusahaan. Bandung : PT Remaja Rosdakarya.

Nurcahya, G.A. 2018. Pengaruh Disiplin Kerja Terhadap Kinerja Karyawan PT Arah Enviromental Indonesia Bag Surakarta. Jurnal E-Proceeding Of Management. Vol 5. No 1. 1-10 pp.

Rivai, V. 2009. Manajemen Sumber Daya Manusia Untuk Perusahaan. Jakarta : PT Raja Grafindo Persada.

Robbins. 2006. Perilaku Organisasi. Jakarta : Bhuana IImu Populer

Sugiyono. 2018. Metode Penelitian Kuantitatif. Cetakan Pertama. Bandung : CV Alfabeta

Sulaksono, H. 2015. Motivasi Kerja dan Kinerja. Cetakan Pertama. Yogyakarta: Depublis. 
